\title{
EDUCATIONAL METHODS TO IMPROVE THE ABILITY OF PARENTS TO PROVIDE DEVELOPMENTAL CARE FOR PREMATURE INFANTS: A LITERATUR REVIEW
}

\author{
Indra Tri Astuti ${ }^{1}$, Moses Glorino Rumambo Pandin² \\ ${ }^{1}$ Student of Doctoral Program In Nursing, Faculty of Nursing, Airlangga University \\ ${ }^{2}$ Associate Professor, Faculty of Cultural Sciences, Airlangga University
}

Email: in.tri.astuti-2020@fkp.unair.ac.id

\begin{abstract}
ABSTACT
Introduction

Babies born prematurely are at risk of experiencing visual disturbances, hearing loss, disabilities, the risk of infection and even death. Care for premature babies requires serious attention for both health workers and parents. The role of parents is very important both during hospitalization and at home. Therefore, in order to improve the abilities of parents, it is necessary to make educational efforts with the right method.

Objectives

This literature review aims to provide an overview of educational methods that nurses can use to improve the ability of parents to care for or care for the development of premature babies.

Methods

The method used is to search for literature that fits the established theme using 5 data based, namely Scopus, ProQuest, Science Direct, Elsevier Clinicaly for Nursing and Web of Science. The strategy used in finding literature that fits the theme and is used in this literature review uses the PICOS framework. Then conducted a review with the PRISMA method.
\end{abstract}

Results

The literature selection results obtained 572 publications, after going through the selection obtained 11 literatures that match the theme, with 11 educational methods. These methods can be grouped into ideas, namely increasing parental involvement during treatment, using technology, stress management and continuous monitoring.

\section{Conclusion}

The ability of parents to care for premature babies is needed in order to minimize complications in infants, reduce morbidity, avoid disabilities, increase growth and development of premature babies optimally and reduce parental stress levels, increase parental confidence and good parents' self-efficacy. Choosing the right educational method can improve the ability of parents to properly care for and provide developmental care for premature babies.

Keywords: educational method, parent, developmental care and premature infant

\section{INTRODUCTION}

\section{Background}

It is estimated that 15 bilion babies born prematurely, about 1 in 10 live birth(1). Indonesia itself is ranked fifth after India, China, Nigeria and Pakistan. The data on the birth of preature babies in Indonesia is as many as 675.000. Approximately 1 million premature babies in the world die from complications that occur (1). Other impacts of birth are high 
morbidity and mortality rates, disabilities, learning difficulties, visual and hearing impairments and susceptibility to infection with infection with infectious diseases in the future (1)

Various studies were developed to prevent and overcome various complications that can occur in premature babies. One methode develop to address this problem The Neonatal Integrative Developmental Care Model describes sevent Neuroprotective Core Measures for Family-Centered Developmental Care (2). Seven things namely The Healing Environment, Partnering with Families, Positioning \& Handling, Safeguarding Sleep, Minimizing Stress \& Pain, Protecting Skin, and Optimizing Nutrition(2). This model requires an active role parent in the care of premature babies. A study in Finland found that parents really want to be responsible for caring for their babies both while still in the hospital an at home. They need nurses to empower them in providing care for their babies (3). One of the efforts to increase the ability of parent to play an active role in caring for premature babies, it is necessary to provide the parents with accurate information. One approach is used by teaching the stress and stability cues of preterm infants and a combination of four parental care involvement activities [PCIAs](4)

Parent who have premature bebies not only need clear information regarding their baby's health development and care. But also need additional emotional support, clear and honest communication, way to deal with stress in dealing with situations as well as knowledge about managing babies in the transition from hospital to home(5). Premature babies and their families also often need ongoing cpmmunity-based care once the baby is at home(6). In this regard, nurses need to identify the specific needs of parents in order to provide optimal support including emotional support(7). The indetification od these needs becomes that basis for a nurse to make an appropriate discharge plan. Discharge planning related studies are develop and it is know tha with proper planning parenta will be a ready to care for their babies at home (8)

The method of providing information greatly affects the ability of parents to absorb information and apply the information obtained. This literatur review discusses various methods that can be used to provide information to increase the knowledge and abilities of parents in providing developmental care or caring premature babies

\section{Context}

This literature review discusses various studies on educational methods or health education for parents to improve the ability of parents to care for or provide developmental care for premature babies. 


\section{Purpose}

The general purpose of this literature review it to describe various educational methods that can improve the ability of parents to provide developmental care for premature babies.

\section{Question}

What educational methods can enhance the role of parent ini providing developmental care for premature babies?

\section{METHOD}

The literature search in this review literature uses 5 data based Scopus, ProQuest, Scient Direct, Elsevier Clinicaly for Nursing dan Web of Science. The data used in the literature search was from March too April 2021. The data used in writing this literature were secondary data obtained not from direct observation but obtained from the results of research that had been conducted by previous researchers. The sources used are in the form of journals both national and international with predetermined themes. The protocol and evaluation of this review literature used the PRISMA checklist. Which was tailored to the objectives of this review literature. Whatever the theme established in this literature is method for enhancing parental participation in developmental care for premature infants. Searching for articles or journals used in this literature uses keywords and Boolean operators (AND, OR, AND NOT) which are used to expand or specify the search, making it easier to find journals that match the theme and will be used in writing this literature. The keywords used in finding jaournals that are in accordance with the review literature are adjusted to the Medical Subject Heading $\mathrm{MeSH})$, the keywords used in the review literature are as follows:

Table 1 Keyword Literature Review

\begin{tabular}{llll}
\hline \multicolumn{1}{c}{$\begin{array}{c}\text { Educational } \\
\text { Methods }\end{array}$} & \multicolumn{1}{c}{ Subjects } & \multicolumn{1}{c}{$\begin{array}{c}\text { Developmental } \\
\text { Care }\end{array}$} & \multicolumn{1}{c}{ Premature } \\
\hline Educational method & Parent & Developmental Care & Premature Infants \\
\hline OR & OR & OR & OR \\
\hline Health Education & Family & Care & Preterm Infants \\
\hline OR & OR & OR & OR \\
\hline Training & Mother & Caring & Premature Babies \\
\hline OR & OR & & OR \\
\hline Education & Father & & Preterm Babies \\
\hline
\end{tabular}


The strategy used in finding literature that fits the theme and is used in this review literature uses the PICOS frameswork, which consists of:

1. Population/ problem namely the population or problem to be analized in accordance with the themes that have been determined in this literature review

2. Intervention, namely the implementation of cases of individuals or communities as well as application of the implementation os studies in accordance with pre determined theme

3. Comparation, is an intervention or other implementation that used as a comparison, if not available, a control group can be used in the selected study.

4. Outcome, namely the results and outcomes obtained in previous studies that are in accordance with the themes specified in this literature review

5. Study design, namely the research design used in the articles to be reviewed .

The PICOS format used in this literature review is described in table 2

Table 2 Literature Review Based On The PICOS Format

\begin{tabular}{|c|c|c|}
\hline Criteria & Inclusion & Exclusion \\
\hline Population/ Problem & $\begin{array}{l}\text { Parent or Family or Mother or } \\
\text { Father }\end{array}$ & $\begin{array}{l}\text { Not Parent or Family or } \\
\text { Mother or Father }\end{array}$ \\
\hline Intervention & Educational method for parent & $\begin{array}{l}\text { Not Educational method for } \\
\text { parent }\end{array}$ \\
\hline Comparation & Role parent & \\
\hline Outcome & $\begin{array}{l}\text { Educational Method For Parent In } \\
\text { Developmental Care For Premature } \\
\text { Infants }\end{array}$ & $\begin{array}{l}\text { Didn't explain about } \\
\text { Educational Methode For } \\
\text { Parent In Developmental } \\
\text { Care For Premature Infants }\end{array}$ \\
\hline $\begin{array}{l}\text { Study Design and } \\
\text { Puplication Tiper }\end{array}$ & $\begin{array}{l}\text { Quasi-experimental studies, } \\
\text { Randomized Control and Trial }\end{array}$ & \\
\hline Publication Years & Post-2021 & Pre-2019 \\
\hline Language & English & Language other than English \\
\hline
\end{tabular}

Based on the literature selection results, 572 publications were obtained from searching data bases. The results of this selection are described in Figure 1. 


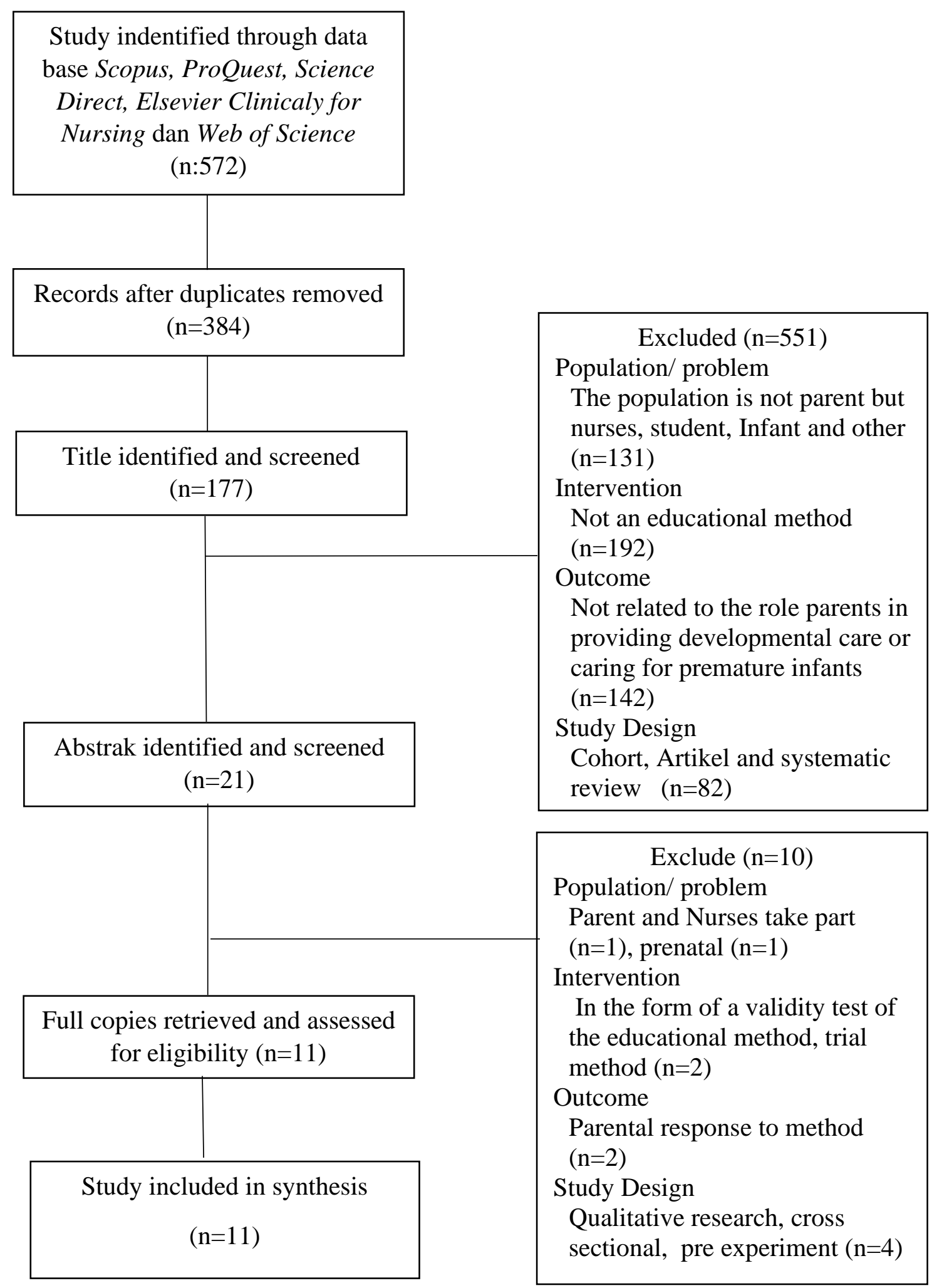

Figure 1 Flow of Literature Review Based on PRISMA 2009 (Polit and Beck, 2013)

Analysis of the methodological quality in each literature obtained was carried out by means of of a checklist of assessment lists with several questions to assess the quality of the literature study critical appraisal 


\section{RESULTS}

The results of a literature study related to educational methods to improve the ability of parents to provide developmental care for premature babies are describe in Table 3

Table 3 Literature Search Results

\begin{tabular}{|c|c|c|c|}
\hline $\begin{array}{c}\text { Author and } \\
\text { Year }\end{array}$ & $\begin{array}{c}\text { Study Design, Sampel, } \\
\text { Variabel, Instrument, } \\
\text { Analysis }\end{array}$ & Outcome & $\begin{array}{l}\text { Summary of } \\
\text { Results }\end{array}$ \\
\hline $\begin{array}{l}\text { Askary, et al. } \\
(2020)\end{array}$ & $\begin{array}{l}\text { Design: Randomized } \\
\text { Controlled Trial (RCT) } \\
\text { Sample: using ramdomized } \\
\text { block design, } 45 \text { respondent } \\
\text { (each group } 15 \text { respondent) } \\
\text { Variable: Creating } \\
\text { Opportunities } \\
\text { for Parent Empowerment } \\
\text { (COPE) program and the } \\
\text { perceived maternal parenting } \\
\text { self-efficacy (PMP-SE) } \\
\text { Instrument: using the } 20 \text {-item } \\
\text { Efficacy subscale of the } \\
\text { Parenting Sense of Competence } \\
\text { scale } \\
\text { Analysis: Anova }\end{array}$ & $\begin{array}{l}\text { Creating } \\
\text { Opportunities } \\
\text { for Parent } \\
\text { Empowerment } \\
\text { (COPE) }\end{array}$ & $\begin{array}{l}\text { COPE can increase } \\
\text { parental confidence, } \\
\text { increase knowledge } \\
\text { as well as the desire } \\
\text { to increase the } \\
\text { ability to care for } \\
\text { premature babies(9) }\end{array}$ \\
\hline $\begin{array}{l}\text { Abbass-Dick, et } \\
\text { al.. (2020) }\end{array}$ & $\begin{array}{l}\text { Design: Randomized } \\
\text { Controlled Trial (RCT) } \\
\text { Sample: sample size of } 112 \text { (56 } \\
\text { per group) } \\
\text { Variable: Breastfeeding } \\
\text { attitude, breastfeeding } \\
\text { knowledge, Breastfeeding self- } \\
\text { efficacy, Breastfeeding partner } \\
\text { support and Breastfeeding co } \\
\text { parenting } \\
\text { Instrument: } \\
\text { Breastfeeding Self-Efficacy } \\
\text { Scale-Short Form (BSES-SF) } \\
\text { and an adapted version for co- } \\
\text { parents (Dennis, 2003b , 2018). } \\
\text { Comprehensive Breastfeeding } \\
\text { Knowledge Scale (CBK S) } \\
\text { (Abbass-Dick et al., 2020). } \\
\text { Iowa Infant Feeding Attitude } \\
\text { Scale (IIFAS) ( de la Mora et } \\
\text { al., } 1999 \text { ). }\end{array}$ & E Health & $\begin{array}{l}\text { The results of this } \\
\text { study indicate that } \\
\text { e-health can help } \\
\text { parents, especially } \\
\text { in finding sources of } \\
\text { information(10). }\end{array}$ \\
\hline
\end{tabular}




\begin{tabular}{|c|c|c|c|}
\hline $\begin{array}{l}\text { Author and } \\
\text { Year }\end{array}$ & $\begin{array}{c}\text { Study Design, Sampel, } \\
\text { Variabel, Instrument, } \\
\text { Analysis }\end{array}$ & Outcome & $\begin{array}{l}\text { Summary of } \\
\text { Results }\end{array}$ \\
\hline & $\begin{array}{l}\text { Postpartum Partner Support } \\
\text { Scale (PPSS; Dennis, Brown \& } \\
\text { Brennenstuhl, 2017), Breast- } \\
\text { feeding Co-parenting } \\
\text { Framework (Abbass-Dick and } \\
\text { Dennis, 2017). }\end{array}$ & & \\
\hline & $\begin{array}{l}\text { Analysis: Chi Square tests and } \\
\text { ANOVA }\end{array}$ & & \\
\hline $\begin{array}{l}\text { Benzies, et al. } \\
2020\end{array}$ & $\begin{array}{l}\text { Design: Randomized } \\
\text { Controlled Trial (RCT) } \\
\text { Sampel: sampling technique } \\
\text { using simple ramdom sampling. } \\
718 \text { infants/614 mothers } \\
\text { (Alberta FiCare group } 353 \\
\text { infants/308 mothers and standar } \\
\text { care } 365 \text { infants/306 mothers) } \\
\text { Variable: } \\
\text { Infant: Primery outcome; } \\
\text { Length of stay, days } \\
\text { Unadjusted. Adjusted for site } \\
\text { geographic area. Adjusted for } \\
\text { site geographic area/ infant risk } \\
\text { factors. Secondary outcomes } \\
\text { Hospital readmission to } 2 \\
\text { months CA. Emergency } \\
\text { department visit to } 2 \text { months } \\
\text { CA. } \\
\text { Maternal Outcome: } \\
\text { psychosocial distress (anxiety, } \\
\text { depressive symptoms, and } \\
\text { stress) and parenting self- } \\
\text { efficacy at discharge. } \\
\text { Instrument: anxiety using the } \\
\text { State-Trait Anxiety Inventory } \\
\text { (STAI), depressive symptoms } \\
\text { using the Edinburgh Postnatal } \\
\text { Depression Scale (EPDS), } \\
\text { stress using the Parental } \\
\text { Stressor Scale: NICU } \\
\text { (PSS:NICU), and parenting } \\
\text { self-efficacy using the } \\
\text { Perceived Maternal Parenting } \\
\text { Self-Efficacy (PMP S-E) tool. } \\
\text { Analysis: Pearson's Chi-square } \\
\text { tests and linear regression. }\end{array}$ & $\begin{array}{l}\text { Alberta Family } \\
\text { Integrated } \\
\text { Care (Alberta } \\
\text { FiCare) }\end{array}$ & $\begin{array}{l}\text { The results obtained } \\
\text { from the Alberte } \\
\text { FiCare application } \\
\text { are, the length of } \\
\text { stay (LOS) is lower, } \\
\text { the re-visits related } \\
\text { to emergencies in } \\
\text { infants are lower, the } \\
\text { type of feeding when } \\
\text { the go home is more } \\
\text { well, maternal } \\
\text { psychosocial stress } \\
\text { and parenting self } \\
\text { efficacy on } \\
\text { discharge from the }\end{array}$ \\
\hline
\end{tabular}




\begin{tabular}{|c|c|c|c|}
\hline $\begin{array}{l}\text { Author and } \\
\text { Year }\end{array}$ & $\begin{array}{l}\text { Study Design, Sampel, } \\
\text { Variabel, Instrument, } \\
\text { Analysis }\end{array}$ & Outcome & $\begin{array}{l}\text { Summary of } \\
\text { Results }\end{array}$ \\
\hline & & & $\begin{array}{l}\text { hospital were } \\
\text { better(11) }\end{array}$ \\
\hline $\begin{array}{l}\text { Montazeri, et al } \\
(2020)\end{array}$ & $\begin{array}{l}\text { Design: Randomized } \\
\text { Controlled Trial (RCT) } \\
\text { Sample: } 70 \text { (participants } \\
\text { ( } 35 \text { in each group), Using } \\
\text { randomized block design } \\
\text { stratified } \\
\text { Variable: Socio-Demographic } \\
\text { characteristics of participants, } \\
\text { nfant sleep quality, anxiety, } \\
\text { frequency of lactation, infant's } \\
\text { anthropometric and } \\
\text { developmental indices } \\
\text { Instrument: Socio- } \\
\text { demographic questionnaire, } \\
\text { Beck Anxiety Inventory (BAI), } \\
\text { Infant Sleep Questionnaire } \\
\text { (ISQ), Ages and Stages } \\
\text { Questionnaire (ASQ), Infant } \\
\text { Anthropometric Parameters } \\
\text { Checklist, and the Exclusive } \\
\text { Breastfeeding Checklist. } \\
\text { Analysis: Chi-square, } \\
\text { independent t, Fisher's exact } \\
\text { tests, ANOVA, }\end{array}$ & $\begin{array}{l}\text { Journal therapy } \\
\text { counseling }\end{array}$ & $\begin{array}{l}\text { The results of this } \\
\text { study explain that } \\
\text { the maternal anxiety } \\
\text { score is lower in the } \\
\text { intervention group } \\
\text { than in the control } \\
\text { group. The } \\
\text { importance of stess } \\
\text { management in } \\
\text { mothers because } \\
\text { mothers who are } \\
\text { anxious and } \\
\text { experiencing } \\
\text { psychological stress } \\
\text { can affect the } \\
\text { quality of sleep of } \\
\text { the baby and the } \\
\text { duration os the } \\
\text { baby's sleep is also } \\
\text { lower (12). }\end{array}$ \\
\hline $\begin{array}{l}\text { Yoo Jin Heo, } \\
\text { Won-Oak Oh } \\
(2019)\end{array}$ & $\begin{array}{l}\text { Design: This study consisted of } \\
\text { two phases. The first phase was } \\
\text { developing the Parent } \\
\text { Participation Improvement } \\
\text { Program. The second phase, a } \\
\text { parallel, 2-group randomized } \\
\text { controlled trial with a } \\
\text { prospective pretest-posttest } \\
\text { experimental design, was } \\
\text { conducted to evaluate the } \\
\text { program's effectiveness. } \\
\text { Sample: total sampel of } 66 \\
\text { premature infants and their } 132 \\
\text { parents (66 mothers and } 66 \\
\text { fathers) were enrolled in this } \\
\text { study. } \\
\text { Variable: Demographic and } \\
\text { clinical characteristics of the } \\
\text { preterm infants and parents }\end{array}$ & $\begin{array}{l}\text { The Parent } \\
\text { Participation. } \\
\text { Improvement } \\
\text { Program }\end{array}$ & $\begin{array}{l}\text { The Parent } \\
\text { Participation } \\
\text { Improvement } \\
\text { Program was proven } \\
\text { effective in } \\
\text { improving parents' } \\
\text { partnerships with } \\
\text { nurses and } \\
\text { attachment to their } \\
\text { infants. The results } \\
\text { are expected to } \\
\text { more effectively } \\
\text { facilitate parent } \\
\text { participation in } \\
\text { neonatal care. }\end{array}$ \\
\hline
\end{tabular}


participation improvement

program

Instrument: The Pediatric

Nurse-Parent Partnership Scale

(Choi and Bang, 2013). The

Maternal Attachment

Inventory, translated into

Korean and revised (Han, 2002),

Analysis:

T-test, chi-squared test. A Shapiro-Wilk test was used to test for normal distribution of the data. Two sample t-tests and a Mann-Whitney U test

Lotfalipour, et al. Design: Quasi experiment (2019) Sample: 52 mother as a respondent, Teknik sampling convinience sampling

Variable:

Mother's Mood State

Instrument: The Profile of Mood State questionnaire Analysis: Kruskal-Wallis, Mann-Whitney U, Wilcoxon, and $\chi 2$ tests.

\begin{tabular}{|c|c|}
\hline $\begin{array}{l}\text { Involved in } \\
\text { nursing action } \\
\text { or nursing } \\
\text { implementation }\end{array}$ & $\begin{array}{l}\text { The results showed } \\
\text { that mothers who } \\
\text { were involved in the } \\
\text { infant massage } \\
\text { intervention } \\
\text { experienced a } \\
\text { greater increase in } \\
\text { mood than the } \\
\text { control group(13). }\end{array}$ \\
\hline
\end{tabular}

Involved in The results showed that mothers who infant massage intervention experienced a mood than the control group(13).

\begin{tabular}{|c|c|c|c|}
\hline $\begin{array}{l}\text { Hunter,et al. } \\
\text { (2021) }\end{array}$ & $\begin{array}{l}\text { Design: one-group } \\
\text { pre-/post-intervention design } \\
\text { Sample: A convenience sample } \\
\text { of mothers of infants admitted } \\
\text { to the SCN was used for this } \\
\text { project. Respondent, } 22 \text { mother } \\
\text { and } 22 \text { infant } \\
\text { Variable:Parental Stress and } \\
\text { Self confidence } \\
\text { Instrument: the } \\
\text { Parental Stress Scale: Neonatal } \\
\text { Intensive Care Unit (PSS: } \\
\text { NICU) and the Perceived } \\
\text { Maternal Parenting Self- } \\
\text { Efficacy } \\
\text { (PMP SE) questionnaire } \\
\text { Analysis: Paired t Test }\end{array}$ & $\begin{array}{l}\text { Help, } \\
\text { Understanding, } \\
\text { and Guidance } \\
\text { (HUG) your } \\
\text { baby }\end{array}$ & $\begin{array}{l}\text { The results showed } \\
\text { a decrease in stress } \\
\text { and an increase in } \\
\text { the confidence of } \\
\text { mothers in caring } \\
\text { for their } \\
\text { children(14) }\end{array}$ \\
\hline $\begin{array}{l}\text { Baraldi, et al. } \\
(2020)\end{array}$ & $\begin{array}{l}\text { Design: Randomized clinical } \\
\text { trial } \\
\text { Sample: Block Randomized, } \\
130 \text { partisipants }\end{array}$ & $\begin{array}{l}\text { Stockholm } \\
\text { preterm } \\
\text { interaction- } \\
\text { based }\end{array}$ & $\begin{array}{l}\text { The results of this } \\
\text { study show positive } \\
\text { results on parent- } \\
\text { child interaction, }\end{array}$ \\
\hline
\end{tabular}




\begin{tabular}{|c|c|c|c|}
\hline & $\begin{array}{l}\text { Variable: Child cognitive } \\
\text { development, Child motor } \\
\text { development, Emotional } \\
\text { availability, Parent-child } \\
\text { interaction, Parental mental } \\
\text { health, Self-regulation } \\
\text { Instrument: Client Satisfaction } \\
\text { Questionnaire (CSQ-8). } \\
\text { Emotional Availability Scales } \\
\text { (EAS), cognitive, language, and } \\
\text { motor development } \\
\text { of the children, Bayley Scales } \\
\text { of Infant and Toddler } \\
\text { Development, Third Edition } \\
\text { (BSID-III), parental } \\
\text { Self-Efficacy Scale (PSE), } \\
\text { Resilience } \\
\text { Scale (RES), Hammersmith } \\
\text { Neonatal Neurological } \\
\text { Outcome (HNNE), Modified } \\
\text { Checklist for Autism in } \\
\text { Toddlers (M-CHAT), Infant } \\
\text { Behaviour Questionnaire (IBQ- } \\
\text { R), Client Satisfaction } \\
\text { Questionnaire (CSQ-8), Child } \\
\text { Engagement Questionnaire } \\
\text { (CEQ), tSwedish questionnaire } \\
\text { Ert Barn Vårt Samspel (EBVS), } \\
\text { the ICF-CY core sets } \\
\text { Analysis: Mann-Whitney U } \\
\text { test, Generalized Estimating } \\
\text { Equation (GEE), Generalized } \\
\text { linear modelling, Poisson } \\
\text { regression model. Person Chi } \\
\text { Square. Qualitative variables } \\
\text { from the } \\
\text { semi-structured interviews will } \\
\text { be analysed for their thematic } \\
\text { content. }\end{array}$ & $\begin{array}{l}\text { intervention } \\
\text { (SPIBI) }\end{array}$ & $\begin{array}{l}\text { child development, } \\
\text { mental health } \\
\text { development of } \\
\text { parents and } \\
\text { children's } \\
\text { participation in } \\
\text { preschool(15) }\end{array}$ \\
\hline $\begin{array}{l}\text { Biarag, et al. } \\
(2021)\end{array}$ & $\begin{array}{l}\text { Design: Randomized controlled } \\
\text { trial } \\
\text { Sample: Block randomization } \\
\text { method. Sample size } 68 \text { (each } \\
\text { group 34) } \\
\text { Variable: supportive } \\
\text { counselling, mental health } \\
\text { (primary outcome), mother- } \\
\text { child bonding and infant } \\
\text { anthropometric indices }\end{array}$ & $\begin{array}{l}\text { Supportive } \\
\text { counseling }\end{array}$ & $\begin{array}{l}\text { Ther results of } \\
\text { this study } \\
\text { explain that } \\
\text { supportive } \\
\text { counselling can } \\
\text { improve mental } \\
\text { health and } \\
\text { postpartum } \\
\text { bonding in the } \\
\text { mothers of }\end{array}$ \\
\hline
\end{tabular}




\begin{tabular}{|c|c|c|c|}
\hline $\begin{array}{c}\text { Author and } \\
\text { Year }\end{array}$ & $\begin{array}{c}\text { Study Design, Sampel, } \\
\text { Variabel, Instrument, } \\
\text { Analysis }\end{array}$ & Outcome & $\begin{array}{l}\text { Summary of } \\
\text { Results }\end{array}$ \\
\hline & $\begin{array}{l}\text { (secondary outcomes) in } \\
\text { mothers of premature infants. } \\
\text { Instrument: General Health } \\
\text { Questionnaire (GHQ) was used } \\
\text { to assess mental health. the } \\
\text { Mental Health Questionnaire, } \\
\text { Postpartum Bonding } \\
\text { Questionnaire and the } \\
\text { anthropometric indices } \\
\text { checklist, (including height, } \\
\text { weight, and head circumference } \\
\text { of the infants) were completed } \\
\text { at week } 8 \text { postpartum. The PBQ } \\
\text { consisted of } 25 \text { items indicating } \\
\text { the mother's } \\
\text { feelings and attitude toward her } \\
\text { infant. } \\
\text { Analysis: Ancova }\end{array}$ & & $\begin{array}{l}\text { premature } \\
\text { babies (16) }\end{array}$ \\
\hline $\begin{array}{l}\text { Gholami, et al. } \\
\text { (2021) }\end{array}$ & $\begin{array}{l}\text { Design: Quasi Experimantal } \\
\text { Study } \\
\text { Sample: Sampel size 288, by } \\
\text { convenience sampling } \\
\text { Variable: telenursing, the rate } \\
\text { of readmissions in premature } \\
\text { infants } \\
\text { Instrument: Mothers and } \\
\text { Infants Demographic and } \\
\text { Clinical information Form and } \\
\text { Awareness Assessment } \\
\text { Checklist } \\
\text { Analysis: Anova, regresi } \\
\text { logistic }\end{array}$ & Telenursing & $\begin{array}{l}\text { The implementation } \\
\text { of educational } \\
\text { intervention through } \\
\text { telenursing reduces } \\
\text { the readmission } \\
\text { rates in premature } \\
\text { infants. Considering } \\
\text { that the provision of } \\
\text { this service is } \\
\text { inexpensive and } \\
\text { easy, it can be } \\
\text { considered as a } \\
\text { strategy to reduce } \\
\text { readmission rates. }\end{array}$ \\
\hline Wu, et al. (2019) & $\begin{array}{l}\text { Design: Ramdomized control } \\
\text { trial } \\
\text { Sample: sample size 200, } \\
\text { Variable: duration of } \\
\text { breastfeeding, exclusive } \\
\text { breastfeeding, knowledge of } \\
\text { mothers about breastfeeding, } \\
\text { early initiation of breastfeeding } \\
\text { and introduction of food } \\
\text { Instrument: questionnaire } \\
\text { explanation, smartphone usage } \\
\text { for collecting data }\end{array}$ & WeChat & $\begin{array}{l}\text { This study proves } \\
\text { that the use of } \\
\text { WChat can increase } \\
\text { exclusive } \\
\text { breastfeeding in } \\
\text { China(17) }\end{array}$ \\
\hline
\end{tabular}




\section{Analysis: Chi Square, Regresi \\ Logistic}

\section{DISCUSSION}

The results of literature study regarding the methods used to improve the ability of parents to provide developmental care for premature babies can be grouped into several ideas:

1. Increase parental involvement during care

The methods used to parental involvement during care include Alberta Family Integrated Care (Alberta FiCare)(11), The Parent Participation Improvement Program(18), Involved in nursing action or nursing implementation(13),

Alberte FiCare is a development of the FiCare method. The FiCare method has been developed to support family involvement in wind care at NICU level III. Alberte FiCare develops the FiCare model for level II NICUs. FiCare is one of the recommended methods for implementing family centered care (FCC) in the NICU. As a result, parent feel respected and dignified. Communication with health workers is good, the information provided by the family is good and complete, the family is also involved in decision making during treatment. The parent are more involved, the length of stay is shorter and the morbidity rateis also low(19). This is one of the bases for developing Alberte FiCare. The Results obtained from the Alberte FiCare application, lower length of stay (LOS), lower re-visits related to emergencies in infants, better types of eating when going home, maternal psychosocial pressure and better parenting self-sefficacy when discharge from the hospital (11).

The Parent Participation Improvement Program aims to develop a program to increase parental participation in caring for infants who are cared for in the Intensive Unit (NICU) and to evaluate their effects on nurse-parent cooperation, closeness to infants and infant weight(18). This research was conducted in two stages, the first to develop a parental participation program, the second phase to conduct a trial program to determine the effectiveness of the program being made. In this second phase, it was carried out in several stages in intervention group, namely the interaction stage, the pre-participation stage and the active participation stage, while the control group was allowed to make regular visits(18). The results showed tha this program was able to increase the cooperation between nurses and parents as well as their closeness to their babies.

2. Using technology to increase the knowledge and abilities or parents in caring for or providing care including E Health(10), Telenursing(20) and WeChat(17)

E-Health is a type of health service that has complex information data. The complexity of e-health can be seen from services which include content, commerce, connectivity, and care. E-health which was developed in the study through 2 stages, namely participants were given access to the parenting website developed, so that they could access them during the perinatal periode(10). The information that can be accessed includes reasons for breastfeeding, how to breastfeed the first days of life, general problems, support from 
mothers/ fathers/ spouses/ partners, where to get help, daily life and useful links(10). Second stage couples who are willing to be informed about the resources of breast milk avalaible resources of breast milk available in the community. This aims to increase cooperation with partners in meeting the goals of breastfeeding(10). The results of this study indicate that e-health an help especially in finding sources of information(10). Another study explains that health education through technology (e-health) can improve optimal health outcomes for infants and their families(21).

The development of e-health is also developed with smartphones. Smartphones have become one of the most reable communication tools in the world, through smartphones people can share information. One of the applications on smartphones is WeChat. In this study, the steps for developing educational techniques using WeChat are as follews: 1) developing information-based data, 2) meeting research groups to identify messages to be published, 3) developing multimedia according to the content to be used, 4) socializing to respondents. (17). The implementation of education using the WeChat application is carried out for the first 1 month after childbirth, then followed by 4 post delivery. Furthermore, a competition was conducted to find out the mother's knowledge about breastfeeding, as well as to monitor the child's growth. Next, online meetings are held and there is a reward for respondent who has a good score. This study proves that the use of WeChat can increase exclusive breastfeeding in China (17)

Other research related to the effectiveness of using smartphones as a medium for health education, also proves that users are satisfied with applications made and increase the tendency of mothers to find out what is needed in caring for their babies(22). The content developed in this study included physical conditions and emotional needs, nutrition, sleep and hygiene, medical and nursing needs as well as vaccinations and growth curves(22).

\section{Stress Manajement}

The mental health of the mother at the time of giving birth to a premature baby is one of the important factors that can affect the mental health of the child and the stability of their family(23). This is because women are more suspectible than men to psychological problems such as depression, anxiety and other disorders(23). The birth of a premature baby can have a psychological impact on the mother, such as changes in mood, stress and depression(13). Treatment of premature babies requires parent to stay in the hospital, where the length of stay can be from days to months. This can negate the psychological impact of the parents, because the NICU is a stressful and environmental stressful place for parents(14).

Good stress management can help parents reduce stress, increase self-confidence and the ability to care for premature babies. Some of the methods obtained in this literature study include involved in nursing action or nursing implementation(13), Help, Understanding, and Guidance (HUG) your baby(14), Journal therapy counseling(12) dan Supportive counseling(16).

Increasing the participation of mothers in the care of premature babies can improve the mental health of mothers. Various methods were carried out by scientists, one of the studies conducted by Lotfalipour, et al, aimed to determine the effect of maternal involvement in one of the selected interventions, namely infant massage on the mother's mood(13). The intervention was carried out for five days, while the results of the study showed a greater improvement in mood compared to the control group(13). 
The HUG Your Baby program was developed to reduce parental stress and increase parental confidence in caring for their babies when they are discharged(14). Interventions are carried out by providing videos and handouts related to standar knowledge usually this interventions id carried out between 4-6 days after the patient is admitted. The next step id for participant to make the program coordinator to face-to-face education, discussion and clarification os the point taught in the HUG program(14). Visits can be made while still being treated and before the baby comes home. Evaluation is carried out by means of a questionnaire and demonstration of the knowledge taught. Some of the things that were evaluated included eating the baby, skin-to-skin contact, holding and talking to the baby, recognizing excessive stimulation or sign and signs of active sleep and restful sleep. The results showed a descrease in stress and an increase in mother confidence in caring for her child (14).

Journal therapy counseling was conducted with three face-to-face journal therapy sessions and three telephone counseling sessions. The results of this study explained that the maternal anxiety score was lower in the intervention group than in the control group. The importance of stress management in mothers because mothers who are anxious and experiencing psychological stress can affect the quality of sleep of the baby and the duration of the baby's sleep is also lower(12). Another study explained that depressed mothers tended to be less close to their babies, they were also less concerned with their babies, had less exercise and also had an effect on the quality of breastfeeding than mothers who were not depressed (24).

The supportive counseling method aims to improve the mental health of mothers who have premature babies, besides this method also aims to improve the bond between mother and baby, and its effect on the growth of premature babies (16). This method was developed in 6 stages starting from introduction, counseling, infant massage training, educational films, to follow-up activities. The results of this study explain that supportive counseling can improve mental health and postpartum bonding in mothers of premature babies (16)

4. Conducting continuous education and monitoring during treatment until at home The results of the literature study obtained several sustainable education and monitoring methods, including Stockholm preterm interaction-based intervention (SPIBI)(15) and Creating Opportunities for Parent Empowerment (COPE).

Stockholm preterm interaction-based intervention (SPIBI)(15), is one of the methods used to improve people's ability to provide developmental care. Stockholm preterm interactionbased intervention (SPIBI) is a planning model or preparation for the discharge of premature babies (discharge planning) in the Intensive Unit (NICU) developed in Stockholm Sweden for extremely preterm (EPT) babies. Interventions from SPIBI are brief, namely providing strength-based support from parent-child interactions, making parents sensitive to baby cues, providing support for further developmental care when they are at home and improving self-regulation and joint regulation (15). The results of this study show positive results on parent-child interaction, child development, mental health development of parents and children's participation in preschool (15) 
Creating Opportunities for Parent Empowerment (COPE) is a behavior education designed to provide support for parents. A study suggests that COPE can reduce stress through increasing parental knowledge and changing beliefs in caring for premature babies (9). The steps for implementing COPE are by providing behavioral education in the form of compact disks (CDs) along with instructions and strengthening activities in the form of workbooks. The COPE program is implemented in four stages. The first is carried out after the baby has been treated for 2- 4 days. The second phase is 2-4 days after the first phase is carried out, the third phase is 1-4 days before discharge, while the fourth phase is carried out 1 week after discharge. This activity is also monitored by a supervisor, apart from serving as a therapist as well as providing daily comments in the workbook. Assessment was followed up for 1 month after discharge. This method can increase parents' confidence, knowledge and also the desire to improve their ability to care for premature babies(9).

This assistance is needed because the process after being discharged from the hospital is the most difficult period for both the baby and the parents. This can affect the quality of life for both mother and family(25). The importance of discharge planning and the development of educational strategies used in training babies and parents since they are still in the hospital is needed, so that the next nursing process when at home can run well and have no impact on babies, mothers and their families.

\section{CONCLUSION}

The ability of parents to care for premature babies is needed is orded to minimeze complicationsnin infants, reduce morbidity, avoid disabilities, increase growth and optimal development of premature babies. In addiction, increasing parental abilities can also reduce parental stress levels, increase parental confidence and selft efficacy of good parents. Selection of the right educational method can improve the care for and provide developmental care for premature babies.

\section{REFERENCES}

1. Lincetto O, Banerjee A. World prematurity day: Improving survival and quality of life for millions of babies born preterm around the world. Am J Physiol - Lung Cell Mol Physiol. 2020;319(5):L871-4.

2. Altimier L, Boyle B. The role of families in providing neuroprotection for infants in the NICU. J Neonatal Nurs. 2019;25(4):155-9.

3. Pellikka HK, Pölkki T, Sankilampi U, Kangasniemi M. Finnish Parents'

Responsibilities for Their Infant's Care When They Stayed in a Single Family Room in a Neonatal Intensive Care Unit. J Pediatr Nurs. 2020;53(2020):e28-34.

4. Melançon J, Aita M, Belzile S, Lavallée A. Clinical intervention involving parents in 
their preterm infant's care to promote parental sensitivity: A case study. J Neonatal Nurs [Internet]. 2021;27(1):58-62. Available from:

https://doi.org/10.1016/j.jnn.2020.05.003

5. Roshaya Zakaria1,2, Rosnah Sutan1 RJ. Developing and implementing a health educational package for preemie moms in the care of their baby after hospital discharge. 2021;1-10.

6. Petty J, Whiting L, Mosenthal A, Fowler C, Elliott D, Green J. The knowledge and learning needs of health professionals in providing support for parents of premature babies at home: A mixed-methods study. J Neonatal Nurs [Internet]. 2019;25(6):27784. Available from: https://doi.org/10.1016/j.jnn.2019.07.002

7. Amorim M, Alves E, Kelly-Irving M, Silva S. Needs of parents of very preterm infants in Neonatal Intensive Care Units: A mixed methods study. Intensive Crit Care Nurs [Internet]. 2019;54(2019):88-95. Available from: https://doi.org/10.1016/j.iccn.2019.05.003

8. Rio L, Tenthorey C, Ramelet AS. Unplanned postdischarge healthcare utilisation, discharge readiness, and perceived quality of teaching in mothers of neonates hospitalized in a neonatal intensive care unit: A descriptive and correlational study. Aust Crit Care. 2021;34(1):9-14.

9. Askary Kachoosangy R , Shafaroodi N , Mohammad Heidarzadeh M, Qorbani M BA, Hejazi Shirmard M DF. Original Article : Increasing Mothers' Confidence and Ability by Creating Opportunities for Parent Empowerment (COPE): A Randomized, Controlled Trial. Iran J Child Neurol winter 2020 Vol 14 No 1. 2020;14(1):77-83.

10. Abbass-Dick J, Sun W, Newport A, Xie F, Godfrey D, Goodman WM. The comparison of access to an eHealth resource to current practice on mother and coparent teamwork and breastfeeding rates: A randomized controlled trial. Midwifery. $2020 ; 90$.

11. Benzies KM, Aziz K, Shah V, Faris P, Isaranuwatchai W, Scotland J, et al. Effectiveness of Alberta Family Integrated Care on infant length of stay in level II neonatal intensive care units: a cluster randomized controlled trial. BMC Pediatr. 2020;20(1):1-12.

12. Montazeri M, Mirghafourvand M, Esmaeilpour K, Mohammad-Alizadeh-Charandabi S, Amiri P. Effects of journal therapy counseling with anxious pregnant women on their infants' sleep quality: A randomized controlled clinical trial. BMC Pediatr. 2020;20(1):1-12. 
13. Lotfalipour B, Tirgari B, Pouraboli B, Mirzaee M. Effect of preterm infant massage by the mother on the mood of mothers having preterm infants. J Chiropr Med [Internet]. 2019;18(1):67-76. Available from: https://doi.org/10.1016/j.jcm.2018.11.001

14. Hunter LML, Blake S, Simmons C, Thompson J, Derouin A. Implementing a Parent Education Program in the Special Care Nursery. J Pediatr Heal Care [Internet]. 2019;33(2):131-7. Available from: https://doi.org/10.1016/j.pedhc.2018.06.007

15. Baraldi E, Allodi MW, Löwing K, Smedler AC, Westrup B, Ådén U. Stockholm preterm interaction-based intervention (SPIBI) - Study protocol for an RCT of a 12month parallel-group post-discharge program for extremely preterm infants and their parents. BMC Pediatr. 2020;20(1):1-18.

16. Seiiedi-Biarag L, Mirghafourvand M, Esmaeilpour K, Hasanpour S. A randomized controlled clinical trial of the effect of supportive counseling on mental health in Iranian mothers of premature infants. BMC Pregnancy Childbirth. 2021;21(1):1-12.

17. Wu Q, Huang Y, Van Velthoven MH, Wang W, Chang S, Zhang Y. The effectiveness of using a WeChat account to improve exclusive breastfeeding in huzhu county qinghai province, China: Protocol for a randomized control trial. Vol. 19, BMC Public Health. BMC Public Health; 2019. p. 1-11.

18. Heo YJ, Oh WO. The effectiveness of a parent participation improvement program for parents on partnership, attachment infant growth in a neonatal intensive care unit: A randomized controlled trial. Int J Nurs Stud [Internet]. 2019;95(2019):19-27. Available from: https://doi.org/10.1016/j.ijnurstu.2019.03.018

19. Lavallée A, De Clifford-Faugère G, Garcia C, Fernandez Oviedo AN, Héon M, Aita M. PART 2: Practice and research recommendations for quality developmental care in the NICU. J Neonatal Nurs [Internet]. 2019;25(4):160-5. Available from: https://doi.org/10.1016/j.jnn.2019.03.008

20. Sara Gholami, Azam Shirinabadi Farahani, Fatemeh Alaee Karahroudy, Farzaneh Moghadam, Nasrin Boromandnia leila khanali M. The effect of telenursing on the rate of newborn readmission. 2021;(March):1-5. Available from: https://www.cochranelibrary.com/central/doi/10.1002/central/CN-02170417/full

21. Monaghan J, Kim T, Dol J, Orovec A, Campbell-Yeo M. Parents' learning needs and preferences in a neonatal intensive care unit: A desire for enhanced communication and eHealth technology. J Neonatal Nurs [Internet]. 2020;26(2):101-5. Available from: https://doi.org/10.1016/j.jnn.2019.09.001

22. Nourani A, Ayatollahi H, Mirnia K. A Smart Phone Application for the Mothers of 
Premature Infants. Irbm [Internet]. 2019;40(5):263-9. Available from: https://doi.org/10.1016/j.irbm.2019.04.006

23. Samani E, Ahmadi A, Sharifi H. Effectiveness of cognitive-behavioral counseling on the mental health of premature infants' mothers in neonatal intensive care unit. J Neonatal Nurs [Internet]. 2020;26(5):263-7. Available from: https://doi.org/10.1016/j.jnn.2020.01.001

24. Webber E, Benedict J. Archives of Psychiatric Nursing Postpartum depression : A multi-disciplinary approach to screening, management and breastfeeding support. Arch Psychiatr Nurs [Internet]. 2021;33(3):284-9. Available from: https://doi.org/10.1016/j.apnu.2019.01.008

25. Granero-Molina J, Fernández Medina IM, Fernández-Sola C, Hernández-Padilla JM, Jiménez Lasserrotte M del M, López Rodríguez M del M. Experiences of Mothers of Extremely Preterm Infants after Hospital Discharge. J Pediatr Nurs [Internet]. 2019;45(2019):e2-8. Available from: https://doi.org/10.1016/j.pedn.2018.12.003 